\section{Pyk2 is a downstream mediator of the IL-2 receptor-coupled Jak signaling pathway}

\author{
Tadaaki Miyazaki, ${ }^{1}$ Akinori Takaoka, ${ }^{1}$ Leonor \\ Nogueira, ${ }^{1}$ I van Dikic, ${ }^{2}$ Hodaka Fujii, ${ }^{1}$ Shiho \\ Tsujino, ${ }^{1}$ Yukiko Mitani, ${ }^{1}$ Michiyuki Maeda, ${ }^{3}$ \\ Joseph Schlessinger, ${ }^{2}$ and Tadatsugu Taniguchi ${ }^{1,4}$ \\ ${ }^{1}$ Department of Immunology, Graduate School of Medicine, \\ University of Tokyo, Bunkyo-ku, Tokyo, 113, Japan; \\ ${ }^{2}$ Department of Pharmacology, N ew York University M edical \\ Center, $\mathrm{N}$ ew York, $\mathrm{N}$ ew Y ork 10016 USA; ${ }^{3}$ Chest Disease \\ Research Institute, Kyoto University, Sakyo-ku, \\ Kyoto, 606-01, Japan
}

\begin{abstract}
Many cytokines transmit signals to the cell interior through activation of receptor-associated, Janus family protein tyrosine kinases (Jak PTKs). The interleukin-2 receptor (IL-2R) is associated with the Jak1 and Jak3 PTKs, and ligand-induced activation of these PTKs is essential for lymphocyte proliferation. Here, the nonreceptor PTK, Pyk2, was found to be activated following IL-2 stimulation in a Jak-dependent manner. Furthermore, physical association was detected between endogenous Pyk2 and Jak3, and a dominant interfering mutant of Pyk2 inhibited IL-2-induced cell proliferation without affecting Stat5 activation. Collectively, these results suggest that Pyk2 is a newly identified component of the Jak-mediated IL-2 signaling pathway.
\end{abstract}

Received December 3, 1997; revised version accepted January 28, 1998.

Interleukin-2 (IL-2), a cytokine critical for Iymphocyte proliferation, transmits the signals to cell interior through binding to IL-2R (receptor), a compl ex composed of the IL-2R $\alpha, \beta C$, and $\gamma \mathrm{C}$ chains (for review, see T aniguchi and Minami 1993; Leonard et al. 1994; Sugamura et al. 1996). It has been shown that the IL-2R $\beta C$ and $\gamma C$ chains are associated with two Janus protein tyrosine kinases (Jak1 and Jak3 PTKs), respectively, and that IL2-induced activation of these PTKs is crucial for invoking cell proliferation (Johnston et al. 1994; Miyazaki et al. 1994; Russell et al. 1994; Witthuhn et al. 1994; Kawahara et al. 1995). Few of the downstream targets of Jak PTKs are known, except for the Stat (signal transducer and activator of transcription) factors (Darnell et al. 1994; Stahl et al. 19995; Ihle 1996). However, IL-2-induced cell proliferation occurs without Stat5 activation in some cells (Fujii et al. 1995), indicating the presence of an additional, unknown target(s) of the Jaks. Pyk2 (CAK $\beta /$ RAFTK), a member of focal adhesion kinase

[Key Words: IL-2; IL-2R; Jak PTK; Pyk2; Stat5]

${ }^{4} \mathrm{C}$ orresponding author.

E-MAIL tada@m.u-tokyo.ac.jp; FAX 81-3-5689-7214.
(FAK) family PTKs (Avraham et al. 1995; Lev et al. 1995; Sasaki et al. 1995), has been characterized as a mediator of G-protein-coupled receptors (Lev et al. 1995) and stress signals, leading to activation of the MAP kinase (Dikic et al. 1996) and Jun N (amino)-terminal kinase (JN K) signaling pathways (Tokiwa et al. 1996), respectively. In addition, Pyk2 was shown to be activated by a variety of extracellular stimuli that el evate intracellular $\mathrm{Ca}^{2+}$ concentration (Lev et al. 1995). N otably, Pyk2 is highly expressed in the cells of the immune system (Avraham et al. 1995; Tokiwa et al. 1996; Qian et al. 1997) in addition to the neuronal system (Lev et al. 1995), and it was shown to be involved in signaling triggered by $T$ cell antigen receptor (TCR) stimulation (Qian et al. 1997). However, the role of Pyk2 in cytokine signaling has been unknown. In the present study, we report on the IL-2-induced activation of Pyk2 and provide evidence demonstrating the role of Pyk2 as a mediator of the IL-2R-Jak signaling pathway.

\section{Results and Discussion}

Pyk2 activation following IL-2R stimulation

Activation of Pyk2 by IL-2 was first examined in human peripheral T lymphocytes. Induction of Pyk2 tyrosine phosphorylation was detectable within 10 min after IL-2 stimulation and persisted for at least 60 min (Fig. 1A, left). N otably, the kinetics of IL-2-induced Pyk2 phosphorylation are similar to those observed for Jak1 and Jak3 (Fig. 1A), suggesting a potential link among these PT Ks in IL-2 signaling (see below). Similar results were obtained with the IL-2-responsive cell clone F-7 (Hatakeyama et al. 1989), which was established from the IL-2R $\alpha^{+}, \beta C^{-}, \gamma C^{+}$, murine hematopoietic cell line BAF-B03 by stable expression of the wild-type IL-2R $\beta C$ cDNA (Fig. 1A, middle). Furthermore, IL-2-induced Pyk2 phosphorylation was al so confirmed with a human $\mathrm{T}$ cell clone WT-24, which was established from the IL-2R $\alpha^{+}$, $\beta \mathrm{C}^{+}, \gamma \mathrm{C}^{-}, \mathrm{ED} 40515(-)$ cell line (Arima et al. 1992) by stable expression of the wild-type IL-2R $\gamma \mathrm{C}$ CDNA (Fig. $1 A$, right). IL-2-induced activation of Pyk2 PTK was demonstrated in both F-7 and WT-24 cells by autophosphorylation and by in vitro phosphorylation of an exogenous substrate (Fig. 1B,C).

Identification of the critical regions of the IL-2R $\beta C$ and $\gamma \mathrm{c}$ chains for Pyk2 activation

The membrane-proximal S-region of IL-2RßC (Hatakeyama et al. 1989) and the 48-amino-acid carboxy-terminal region of IL-2R $\gamma \mathrm{C}$ are essential for IL-2 signaling (A sao et al. 1993; Ishii et al. 1994) (Fig. 2A). In fact, these two regions are critical for the interaction with Jak 1 and Jak3, respectively, and for the activation of both Jak kinases (Ishii et al. 1994; Johnston et al. 1994; M iyazaki et al. 1994; Russell et al. 1994; Witthuhn et al. 1994; Nelson et al. 1996). We thus examined whether these regions are also critical for Pyk2 activation. As shown in 

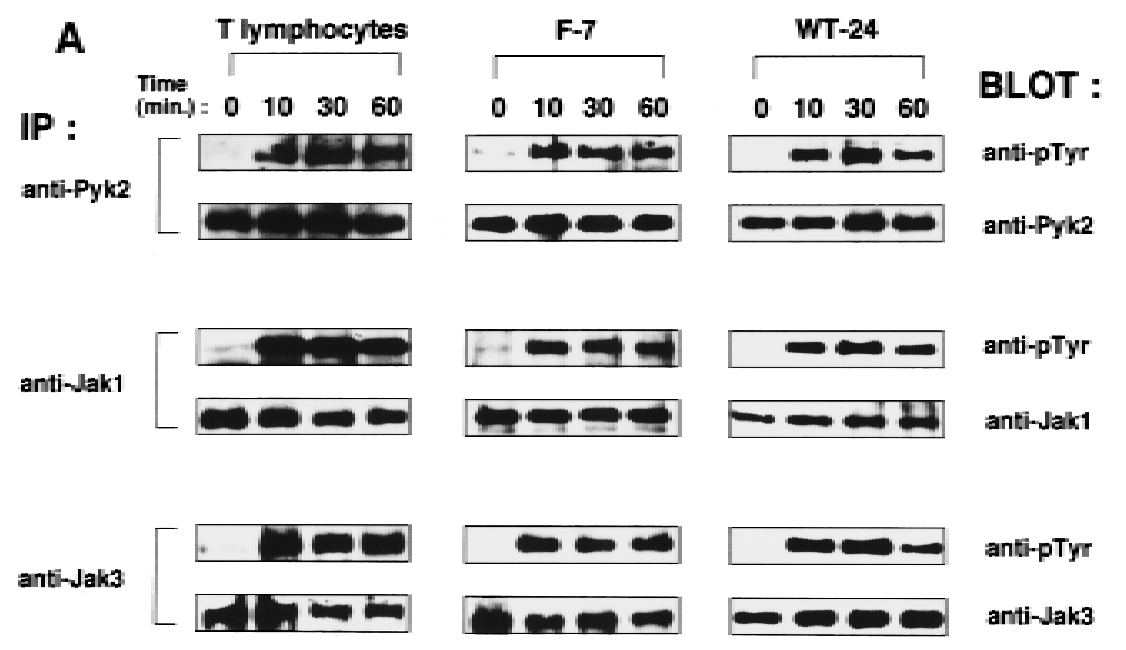

B
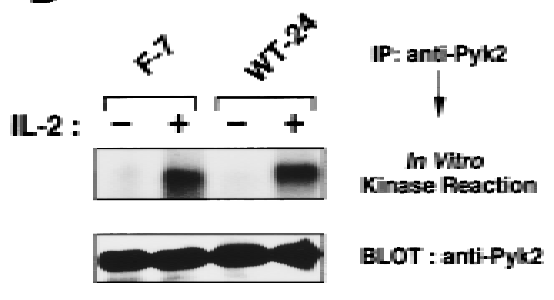

C

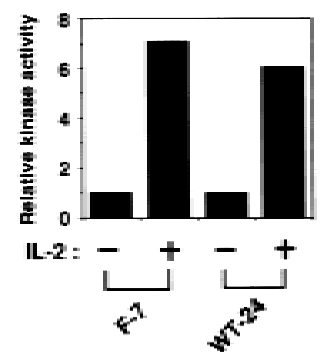

Figure 1. Activation of Pyk2 following IL-2R stimulation. (A) Time course of IL-2induced tyrosine phosphorylation of Pyk2, Jak1, and Jak3 in human peripheral $T$ lymphocytes, F-7, and WT-24 cells. Quiescent T Iymphocytes and F-7 cells or WT-24 cells were stimulated with IL-2 for the indicated intervals (see M aterials and M ethods). Cell lysates from these cells were subjected to immunoprecipitation (IP) and analyzed by immunoblotting (BLOT). (B) A utophosphorylation of Pyk2 following IL-2 stimulation. Factor-starved F-7 or WT-24 cells were stimulated $(+)$ or not $(-\rightarrow$ with IL-2 for 30 min. Pyk2 was immunoprecipitated from these cells, and the immunoprecipitates were subjected to an in vitro kinase assay or immunoblotting with anti-Pyk2 antibody. The phosphorylated products were analyzed by autoradiography. (C) Tyrosine phosphorylation of exogenous substrate by Pyk2. Immunoprecipitated Pyk2 from F-7 or WT-24 cells, stimulated (+) or not ( $\rightarrow$ with IL-2 as described in B, were subjected to an in vitro kinase assay in the presence of the exogenous substrate, poly(Glu-Tyr) (4:1), as reported by Lev et al. (1995). The phosphorylated products were anal yzed by autoradi ography, and quantified by the incorporated radi oactivity of the phosphorylated poly(Glu-Tyr). The data are presented as kinase activity relative to unstimulated cells.

Figure 2B (top), IL-2-induced tyrosine phosphorylation of Pyk2 does not occur in BAF-B03-derived S-25 cells, which express a mutant IL-2R $\beta$ C lacking the $S$ region ( $S$ mutant). On the other hand, Pyk2 phosphorylation is still seen in A-15 cells, which express a mutant IL-2R $\beta C$ lacking the $A$ region (A mutant) (Fig. $2 A$ ). The $A$ region is essential for the binding and activation of src family members, for example, Lck, but not for Jak 1 (Taniguchi 1995; M iyazaki and Taniguchi 1996), indicating that the former PTKs are not involved in the IL-2-induced Pyk2 activation. As for IL-2R $\gamma \mathrm{C}$, tyrosine phosphorylation of Pyk2 was no longer observed in M 2-7 cells, which express a mutant IL-2R $\gamma \mathrm{C}$ lacking its carboxy-terminal 48 amino acids (Fig. 2, A and B, bottom), a region that is critical for Jak3 binding (M iyazaki et al. 1994; Russell et al. 1994). These results suggest that IL-2-induced Pyk2 phosphorylation/activation may be triggered by the Jak $1 /$ Jak3 signaling pathway.

Requirement of the Jak signaling pathway for Pyk2 activation

To study further the functional relationship between Pyk2 and the Jaks, Pyk2 activation was compared in the F-7-derived clones FJM-13 and FJ3-6, which overexpress a dominant interfering mutant and the wild-type Jak3 molecule, re spectively (Kawahara et al. 1995). It was found that in FJM-13 cells, in which IL2-induced activation of Jak 1 and Jak 3 is inhibited (Kawahara et al. 1995), Pyk2 phosphorylation was also inhibited (Fig. 3A). To examine further the role of the Jaks, IL-2-induced Pyk2 phosphorylation was examined in NIH-3T3-derived cell lines expressing IL-2R (Miyazaki et al. 1994). The cell line 3T $3 \alpha \beta \gamma$, which expresses all three IL-2R chains from transfected cDN As, was establi shed (M inami et al. 1994). 3T $3 \alpha \beta \gamma$ expresses endogenous Jak1 but not Jak3. A nother cell line, J3, was establ ished from $3 T 3 \alpha \beta \gamma$ by expressing the cDNA encoding Jak3, which became responsive to IL-2 for cell proliferation in the absence of serum (Miyazaki et al. 1994). As shown in Figure $3 B$, expression of the CDNA-driven human Pyk2 was detected similarly be tween the establ ished cl ones $\alpha \beta \gamma \mathrm{P}-4$ and J3P-1; however, induction of Pyk2 phosphorylation by IL-2 was observed only in the latter cells expressing Jak3. Furthermore, tyrosine phosphorylation of endogenous Pyk 2 was induced in $\mathrm{J} 3$ but not in $3 T 3 \alpha \beta \gamma$ (data not shown). These results indicate that the Jak signaling pathway may participate in Pyk2 phosphorylation/activation.

The above observations prompted us to examine whether Pyk2 can associate with Jaks or Syk, another tyrosine kinase that associates with the $S$ region of IL-2R $\beta$ (M inami et al. 1995). COS cells were transfected with an expression vector for Pyk2, together with either of the PTK expression vectors. Then, cell lysates were subjected to immunoprecipitation with anti-Pyk2 antibody, which was followed by immunoblotting with respective PTK antibodies. As shown in Figure $3 \mathrm{C}$ (top, lanes 2, 4, and 6), Jak3 was coimmunoprecipitated with Pyk2, whereas Jak 1 and Syk were not. Furthermore, the in vitro kinase assay results (data not shown) are consistent with the notion that Jak3 can phosphorylate Pyk2 di rectly. Perhaps more importantly, association between 
Miyazaki et al.
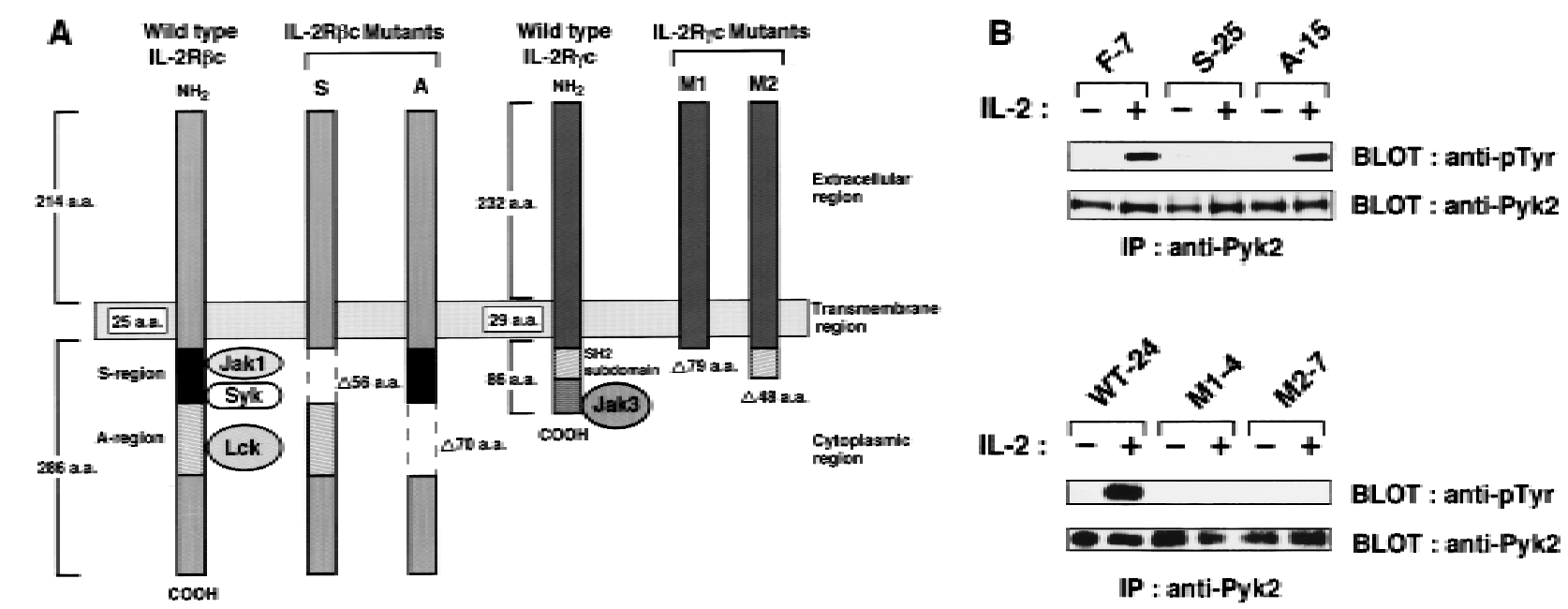

Figure 2. Critical regions of the IL-2R $\beta C$ and $\gamma c$ chains for the IL-2-induced Pyk2 activation. (A) A schematic representation of the wild-type and mutant forms of IL-2R $\beta C$ and $\gamma \mathrm{C}$ (see text and $\mathrm{M}$ aterials and $\mathrm{M}$ ethods for details). (B) Identification of the critical regions of the IL-2R $\beta C$ and $\gamma \mathrm{C}$ chains for the activation of Pyk2. Factor-starved F-7, S-25 or A-15 cells were cultured in the presence (+) or absence ( $\rightarrow$ of IL-2 for $30 \mathrm{~min}$, and cell Iysates were prepared. The lysates were subjected to immunoprecipitation (IP) with anti-Pyk2 antibody and subsequent immunoblotting (BLOT) with anti-pTyr or anti-Pyk2 antibody. The expression levels of the wild-type and mutant IL-2R $\beta C$ in these cells were comparable (Hatakeyama et al. 1989). Clones M 1-4 and M 2-7 express the M 1 and M2 mutants, respectively (see $M$ aterials and M ethods). The expression levels of the wild-type and mutant IL-2R $\gamma \mathrm{C}$ were similar, as reveal ed by FACS analysis (data not shown). Pyk2 activation by IL-2 was analyzed by the same procedures described above.

endogenous Pyk2 and Jak3 was observed in F-7 cells (Fig. 3D) before and after IL-2 stimulation.

The functional role of Pyk2 on IL-2-induced growth and Stat5 activation

It was shown previously that a kinase-negative mutant of Pyk2 (PKM) acts as an inhibitor of wild-type Pyk2mediated activation of M AP kinase induced by lysophosphatidic acid (LPA) or bradykinin (Dikic et al. 1996). To assess the functional role of Pyk2 in the proliferative signal transmission elicited by IL-2, we examined the effect of PKM on the growth of F-7 cells. Because PKM may affect IL-3-induced proliferation of F-7 during CDNA transfection and clonal selection, a tetracyclineinducible promoter-based expression system (Gossen et al. 1995) was employed for the expression of the PKM CDNA (see Materials and Methods). Two independent F-7-derived transformants, FPM-8 and FPM-12, were obtained that expressed high levels of PKM on addition of a tetracycline derivative, doxycycline (Dox) (at least 10fold over endogenous Pyk2) (data not shown). Clones FP11 and FP-14, which express wild-type Pyk2 at levels similar to that of PKM in the previous clones, were established by similar methods. As shown in Figure 4A, IL-2-induced activation of Pyk2 is strongly inhibited in Dox-treated FPM-8 and FPM-12 cells. Concomitantly, IL-2-induced thymidine uptake (data not shown) and cell proliferation (Fig. 4B) were al so inhibited in these cells. We al so tested the effect of overexpression of PKM on the NIH-3T3-derived cell line J3, which expresses low levels of endogenous Pyk2 (data not shown) and proliferates in response to IL-2 stimulation (Miyazaki et al. 1994). As shown in Figure 4C, expression of the PKM
CDN A (J3PM -3 cells) al so inhibited IL-2-induced cell proliferation. On the other hand, PKM expression showed no effect on platelet derived growth factor (PDGF)-induced cell proliferation (Fig. 4C), supporting the notion that PKM selectively inhibits the IL-2R-Jak pathway. In addition, we also examined the effect of antisense oligonucleotides against Pyk2 on IL-2 signaling and found that IL-2-induced thymidine uptake was inhi bited by the Pyk2 antisense (5'-GGCTCGGACACCCCAGACAT-3') but not sense (5'-ATGTCTGGGGTGTCCGAGCC-3') oligonucleotides in both human IL-2-dependent T-cell lines, Kit225 (A rima et al. 1992) and ILT-M at (T akeshita et al. 1989; data not shown).

It has been well-established that cytokine-induced activation of Jak PTKs results in tyrosine phosphorylation of Stat factors to induce their DNA-binding activities. We therefore examined whether or not the expression of PKM affects the IL-2-induced tyrosine phosphorylation and DN A-binding activity of Stat5. IL-2 stimulation of F-7 and derivative clones expressing either wild-type Pyk2 or PKM all showed similar tyrosine phosphorylation levels for Stat5 (data not shown) and similar induction of Stat5 DN A-binding activities (Fig. 4D; Fujii et al. 1995; data not shown). Furthermore, we found that PKM has no effect on the transcriptional activity of Stat5 induced by IL-2.

Our results indicate that Pyk2 is a critical mediator of IL-2 signaling. We infer that Pyk2 is also involved in other cytokine signaling, as PKM expression in FPM-8 and FPM-12 cells also inhibited IL-3-induced cell proliferation (data not shown), suggesting a role for Pyk2 in Jak2-mediated signaling (Ihle 1995; Tani guchi 1995; Miyazaki and Taniguchi 1996). Our results suggest the diversification of the Jak signaling pathway, wherein the 

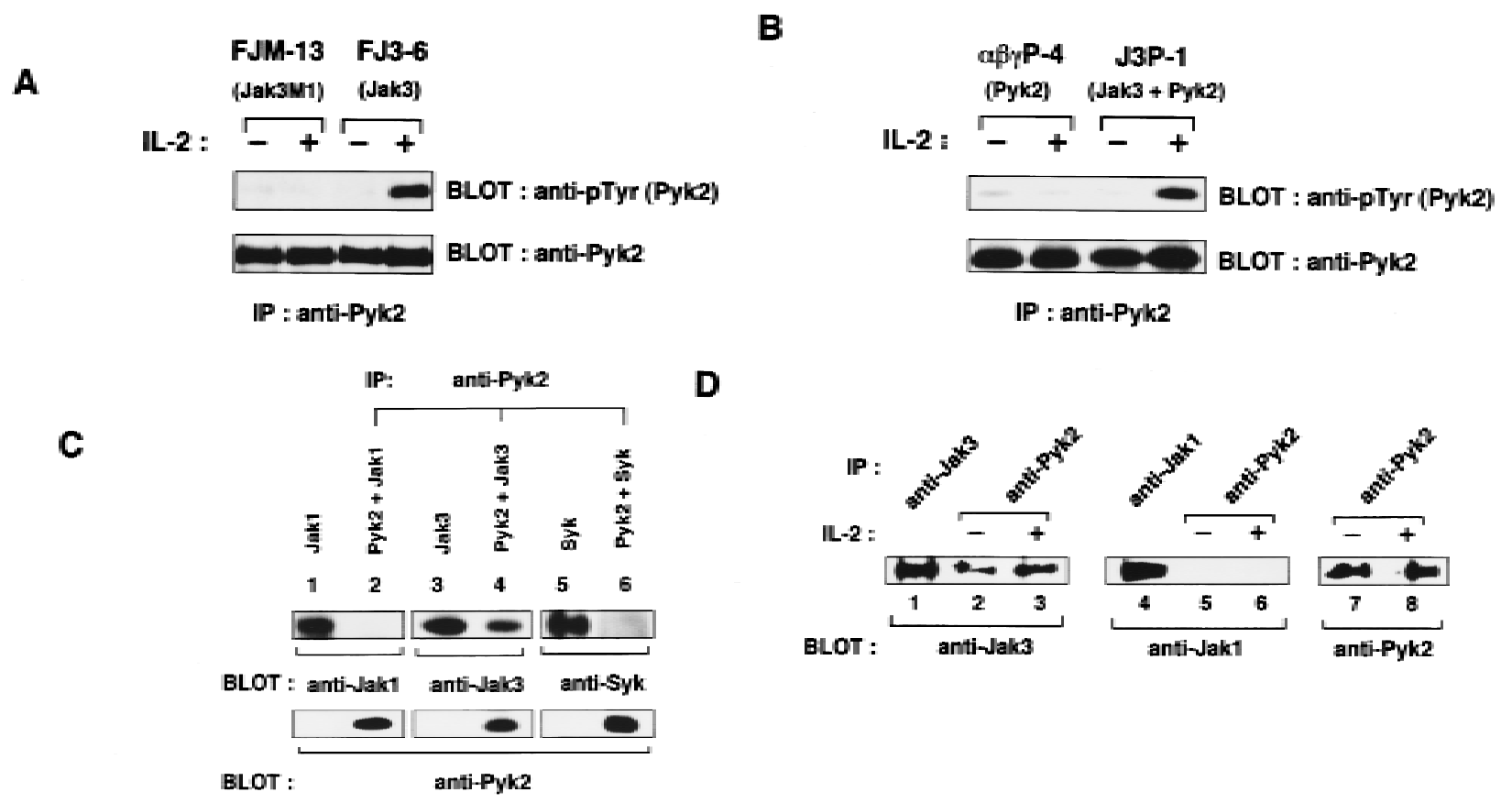

Figure 3. Requirement of the Jak signaling pathway for Pyk2 activation. (A) Inhibition of IL-2-induced Pyk2 activation by Jak3M 1 , a dominant-interfering mutant of Jak3. Factor-starved FJM-13 and FJ3-6 cells were cultured in the presence (+) or absence ( $\rightarrow$ of IL-2 for $30 \mathrm{~min}$, and the cell lysates were immunoprecipitated (IP) with anti-Pyk2 antiody and immunoblotted (BLOT) with anti-pTyr or anti-Pyk2 antibody. These cel Is express similar levels of the cD N A-directed Jak molecules. (B) Requirement of Jak3 in Pyk2 activation by IL-2. $\alpha \beta \gamma \mathrm{P}-4$ and J3P-1 cells $\left(1 \times 10^{7}\right)$ were serum-starved and stimulated $(+)$ or not $(-)$ with IL-2 $(5 \mathrm{~nm})$ for $30 \mathrm{~min}$ and analyzed as in A. $\alpha \beta \gamma$ P-4 expresses Pyk 2 CDN A, and J3P-1 expresses Jak3 and Pyk2 CDN A. (C) The sel ective association of Pyk2 with Jak3. After COS cells were transfected with CDNA expression vector, pEF-Pyk2, together with pEF-Jak1, pEF-Jak3 (Miyazaki et al. 1994), or pEF-Syk (M inami et al. 1995), cell lysates were immunopreci pitated (IP) with anti-Pyk2 anti body (lanes $2,4,6)$ and immunobl otted with antibodies as indicated. As controls, cell lysates of COS cells transfected with the expression vector, pEF-Jak1, pEF-Jak3, or pEF-Syk were subjected to immunoblotting with antibodies against the respective molecules (lanes 1,3,5). Under the same conditions, Pyk2 association with the cytoplasmic regions of the IL-2R $\beta C$ and $\gamma c$ chains (M iyazaki et al. 1994) was not detected (data not shown). (D) Constitutive association of Pyk2 with Jak3. Cell lysates of factor-starved F-7 cells $\left(2 \times 10^{8}\right)$ were prepared before $(-)$ or after $(+)$ IL-2 stimulation for $60 \mathrm{~min}$; immunoprecipitated with anti-Pyk2 antibody (lanes 2,3,5-8); and immunoblotted with anti-Jak3 (lanes 2,3), anti-Jak1 (lanes 5,6), or anti-Pyk2 (lanes 7,8) antibody. As controls, the F-7 cell lysates were immunoprecipitated and immunobl otted for the expression of Jak3 (lane 1) and Jak1 (lane 4). This association was al so observed in human peripheral T Iymphocytes and J3P-1 cells (data not shown).

Stat and Pyk2 pathways function independently of one another. Consistently, IL-2-induced activation of Jak3 remains unaffected by PKM (data not shown). In view of our findings that Pyk2 but not Stat5 is required for IL-2induced cell prol iferation in F-7 cells, the Jak-Pyk2 pathway must be linked to a downstream target(s) other than Stat5. How Pyk2 participates in the regulation of other Jak-associated molecules (Endo et al. 1997; $\mathrm{N}$ aka et al. 1997; Starr et al. 1997; Takeshita et al. 1997) remains to be clarified. The present work offers another example of a signaling cascade involving PTK and suggests a unique convergence of the cytokine receptor-Jak signaling pathway and mitogenic G-protein-coupled receptor signaling pathway through Pyk2.

\section{Materials and methods}

Cells and culture conditions

Human peripheral blood lymphocytes were isolated from normal adults by Ficoll-Hypaque centrifugation and cultured in RPMI1640 supplemented with $10 \%(\mathrm{vol} / \mathrm{vol}) \mathrm{FCS}$ in the presence of Con A at $10 \mu \mathrm{g} / \mathrm{ml}$ for 3 days. Peripheral $T$ lymphocytes were subsequently cultured and enriched in RPM I1640 supplemented with human recombinant IL-2 (Tak- eda Chemicals, Japan) for 7 days. BAF-B03-derived F-7, A-15, S-25, FJ3-6, and FJM-13 cells were cultured as described previously (Hatakeyama et al. 1989; Kawahara et al. 1995). ED 40515 ( $\rightarrow$ was cultured in RPMI1640 supplemented with $10 \% \mathrm{FCS}(\mathrm{vol} / \mathrm{vol})$. COS, $3 \mathrm{~T} 3 \alpha \beta \gamma$, and J3 cells were cultured as described previously (Miyazaki et al. 1994).

Cell lysis, stimulation, immunoprecipitation, immunoblotting, and in vitro kinase assay

Cell lysis, immunoprecipitation, immunoblotting, and in vitro kinase assays were carried out as described previously (Miyazaki et al. 1994; Lev et al. 1995; Dikic et al. 1996; Qian et al. 1997). Unless stated, the cell number used in these assays was $5 \times 10^{7}$, and human IL-2 was used at $2 \mathrm{~nm}$. Peripheral T Iymphocytes or F-7 cells were washed with PBS three times, cells were cultured with RPMI1640/10\% (vol/vol) FCS for 24 and $12 \mathrm{hr}$, respectively, and stimulated with IL-2. For immunoprecipitation and immunoblotting of Pyk2, rabbit antiserum against Pyk2 (no. 600) was used as described (Dikic et al. 1996). Antibodies against phosphotyrosine (4G 10), Jak 1, and Jak3 were obtained from U pstate Biotechnology for immunoprecipitation and immunoblotting analyses (M iyazaki et al. 1994). For immunoblotting of Syk, rabbit anti-Syk antibody was used as described (M inami et al. 1995).

Plasmid construction and DNA transfection

The CDNA encoding IL-2R $\gamma \mathrm{M} 2$, which lacks the carboxy-terminal 48 amino acids of the human IL-2R $\gamma \mathrm{C}$ chain, was generated by PCR and cloned into the pEF expression vector (Kawahara et al. 1994; H. Fujii, S. Tsujino, and T. Miyazaki, in prep.). WT-24, M 1-4, and M 2-7 cells were 
A
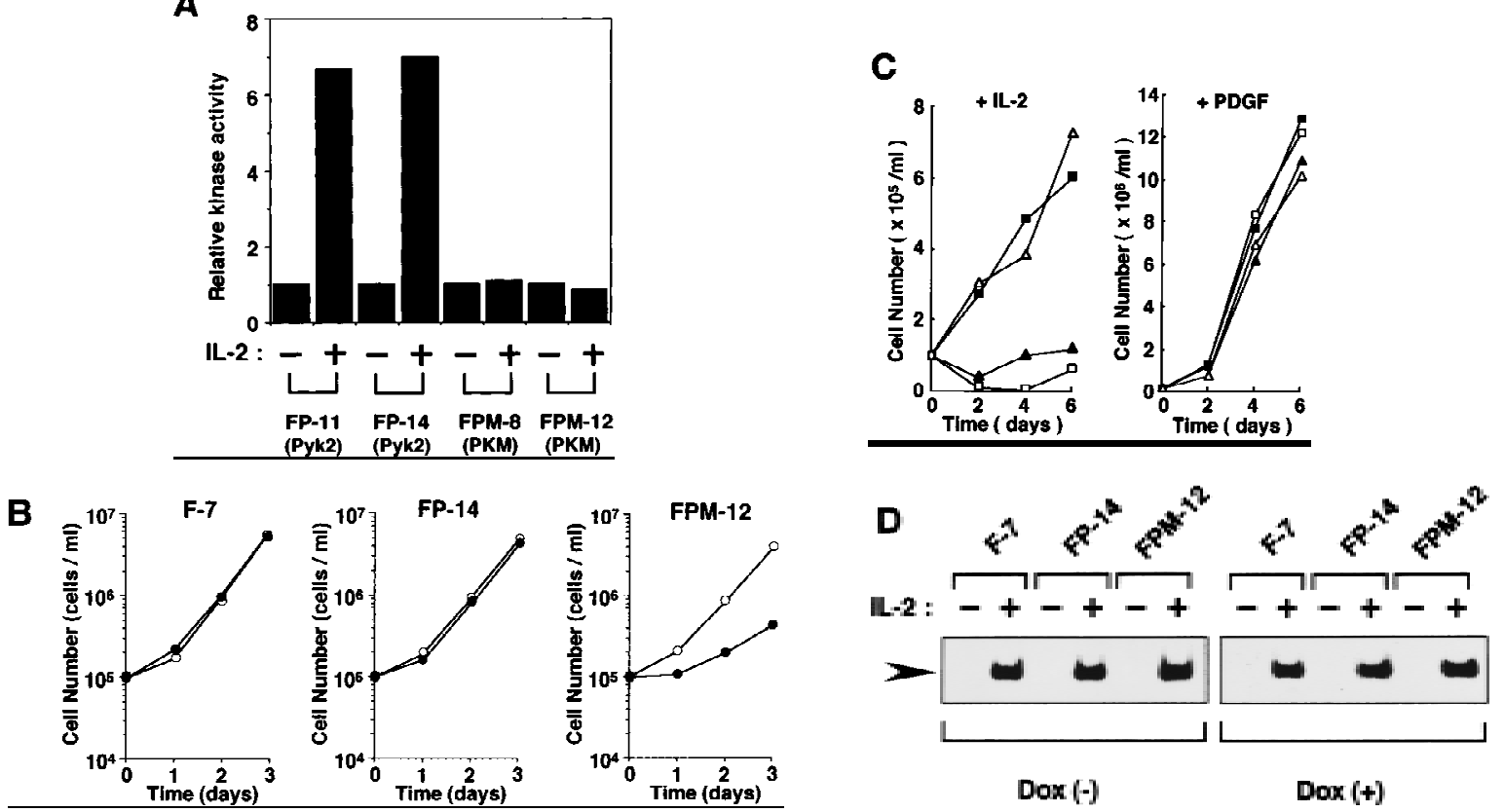

Figure 4. Effects of the overexpressed Pyk2 or PKM on IL-2-induced growth and Stat5 activation. (A) Effect of PKM on IL-2-induced Pyk2 activation. FP-11, FP-14, FPM-8, and FPM-12 cells were incubated in culture medium in the presence of $1 \mu \mathrm{g} / \mathrm{ml}$ Dox for 1 day and cultured in the presence $(+)$ or absence $(-)$ of IL-2 for $30 \mathrm{~min}$. Pyk2 was immunoprecipitated from these cells, and subjected to an in vitro kinase assay as described in Fig. 1. (B) Effect of PKM on IL-2-induced proliferation of F-7-derived cl ones. F-7, FP-14, and FPM-12 cells were incubated in the presence $(\bullet)$ or absence $(O)$ of Dox for 1 day. After factor starvation, cells were incubated with IL-2, and the viable cell numbers were counted. F-7, FP, and FPM cells were analyzed for their abilities to incorporate $\left[{ }^{3} \mathrm{H}\right]$ thymidine in response to IL-2 in the presence or absence of Dox. Incorporation of $\left[{ }^{3} \mathrm{H}\right]$ thymidine by IL-2 was inhibited selectively in the presence of Dox in FPM cells (data not shown). The expression of Jak3M 1, a dominant-interfering mutant of Jak3, in F-7 cells results in growth inhibition of ${ }^{3} \mathrm{H}$ ]thymidine uptake (Kawahara et al. 1995) and cell proliferation (A. Kawahara, unpubl.) at levels similar to that caused by PKM . (C) Effect of PKM on IL-2-induced proliferation of J3-derived clones. 3T $3 \alpha \beta \gamma$ ( $\square$ ), J3 (ם), and J3-derived clones, J3P-1 ( $\triangle$ ) and J3PM-3 $(\mathbf{\Lambda})$, were cultured (see M aterials and M ethods). These cells were incubated with IL-2 or PDGF-AB after FCS starvation for 24 hr, and the viable cell numbers were counted by trypan blue staining. Essentially identical results were obtained in the three independent experiments. (D) Effect of PKM on IL-2-induced DN A-binding activity of Stat5. F-7, FP-14, and FPM-12 cells were incubated with (+) or without $(\rightarrow$ Dox, and stimulated $(+)$ or not $(\rightarrow$ with IL-2 for $15 \mathrm{~min}$. Cell extracts were prepared and subjected to EMSA, using a ${ }^{32} \mathrm{P}$-label ed probe DN A containing the IRF-1-derived GAS el ement (Fujii et al. 1995). Complexes were separated by $4 \%$ acrylamide gel and detected by autoradiography. The positions of IL-2-induced DN A-binding complex are shown (arrowhead). The IL-2-induced Stat activities in F-7 cells are exclusively Stat5 (Fujii et al. 1995; data not shown). Essentially identical results were obtained in other FP and FPM clones, FP-11 and RPM-8 in B and D.

established by transfecting the expression vector plasmids for the wildtype IL-2R $\gamma$ c, the mutant IL-2R $\gamma M 1$ (Kawahara et al. 1994), and IL$2 \mathrm{R} \gamma \mathrm{M} 2$, respectively, with a hygromycin-resistance gene into ED 40515 $\rightarrow$ cells by electroporation (M iyazaki et al. 1991). Expression of wild-type or mutant IL-2R $\gamma \mathrm{C}$ was analyzed by a FACS Caliber Flow Cytometer (Beckton-Dickinson). The wild-type or mutant Pyk2 (PKM) CDN A was subcloned into $\mathrm{pEF}$ vector to generate the expression vectors pEF-Pyk2 or pEF-PKM, respectively. $\alpha \beta \gamma \mathrm{P}-4$ and J3P-1 cells were obtained by cotransfection of pEF-Pyk2 plasmid with the blasticidin-resistance gene into $3 \mathrm{~T} 3 \alpha \beta \gamma$ or J3-13 cells, respectively, by the cal cium phosphate method (Miyazaki et al. 1991). Similarly, J3PM-3 cells were obtained by transfection of pEF-PKM plasmid with the blasticidinresistance gene into J3-13 cells. The wild-type or mutant Pyk2 (PKM) cDN A was subcloned into the plasmid pU HD 10-3 to generate inducible expression vectors for wild-type Pyk2 or PKM, respectively. FP and FPM cells were generated by cotransfecting the plasmids encoding the reverse tetracycline (TC)-controlled transactivator (rtTA), pUHD172-1 neo (Gossen et al. 1995), and pUHD10-3-derived expression vector for Pyk2 or PKM CDNA, al ong with the hygromycin-resistance gene into F-7 cells by el ectroporation. Selection was initiated $24 \mathrm{hr}$ after transfection. Transfection of plasmids, pEF vector (control), pEF-Pyk2, pEF-Jak1, pEF-Jak3 (Miyazaki et al. 1994), or pEF-Syk (Minami et al. 1995) into COS cells was performed by the calcium phosphate method.
Cell growth assay

For cell growth analysis of F-7 or F-7-derived cells, cells were seeded into six-well plates at $1 \times 10^{5} \mathrm{cell} / \mathrm{s} / \mathrm{ml}$ in RPM I 1640 medium/10\% FCS. After factor starvation, cells were stimulated by IL-2. For cell growth analysis in $3 T 3 \alpha \beta \gamma, J 3$, and J3-derived cells, cells were seeded into six-well plates at $1 \times 10^{5}$ cells $/ \mathrm{ml}$ in Dulbecco's modified Eagle medium (DMEM; GIBCO BRL)/ $10 \%$ FCS. After $24 \mathrm{hr}$, cells were starved of FCS and subsequently stimulated by IL-2 ( $5 \mathrm{~nm}$ ) or $20 \mathrm{ng} / \mathrm{ml}$ PDGF-AB (supplemented with $10 \%$ FCS). The viable cell number was counted by trypan blue staining.

\section{Acknowledgments}

We thank J.N. Ihle for the Jak 1 and Jak3 CDN A, H. Yamamura for the Syk CDNA and anti-Syk antibody, H. Bujard for the tetracycline-inducible expression system, T. Sasaki for the poly(Glu-Tyr) substrate, and M.S. Lamphier and E.L. Barsoumian for inval uable suggestions. This work was supported by the Research for the Future (RFTF) Program (96L00307) from the Japan Society for the Promotion of Science (JSPS) and by a special grant for Advanced Research on Cancer, a grant for Molecular Pathogenesis, Grant-in-Aid for Scientific Research on Priority Areas (09273105) and Intervention of Immune Disorders from the Ministry of Education, Science and Culture of Japan and a grant for the Human Frontier Science Program Organization (HFSP). A.T. is a JSPS Research Asso- 
ciate and H.F. is a JSPS Research Fellow. L.N. is a European Union Science and Technology Fellow.

The publication costs of this article were defrayed in part by payment of page charges. This article must therefore be hereby marked "advertisement" in accordance with 18 USC section 1734 solely to indicate this fact.

\section{References}

Arima, N., M. Kamio, K. Imada, T. Hori, T. Hattori, M. Tsudo, M. Okuma, and T. Uchiyama. 1992. Pseudo-high affinity interleukin-2 (IL-2) receptor lacks the third component that is essential for functional IL-2 binding and signaling. J. Exp. Med. 176: 1265-1272.

Asao, H., T. Takeshita, N. Ishii, S. Kumaki, M. Nakamura, and K. Sugamura. 1993. Reconstitution of functional interleukin-2 receptor complexes on fibroblastoid cells: Involvement of the cytoplasmic domain of the $\gamma$ chain in two distinct signaling pathways. Proc. Natl. Acad. Sci. 90: 4127-4131.

Avraham, S., R. London, Y. Fu, S. Ota, D. Hiregowdara, J. Li, S. Jiang L.M. Pasztor, R.A. White, J.E. Groopman, and H. Avraham. 1995. Identification and characterization of a novel related adhesion focal tyrosine kinase (RAFTK) from megakaryocytes and brain. J. Biol. Chem. 270: 27742-27751.

DarnelI, J.E., Jr., I.M. Kerr, and G.R. Stark. 1994. Jak-ST AT pathways and transcriptional activation in response to IFN $s$ and other extracellular signaling proteins. Science 264: 1415-1421.

Dikic, I., G. Tokiwa, S. Lev, S.A. Courtneidge, and J. Schlessinger. 1996. A role for Pyk2 and Src in linking G-protein-coupled receptors with MAP kinase activation. Nature 383: 547-550.

Endo, T.A., M. Masuhara, M. Yokouchi, R. Suzuki, H. Sakamoto, K. Mitsui, A. Matsumoto, S. Tanimura, M. Ohtsubo, H. Misawa, T. Miyazaki, L. N ogueira, T. Taniguchi, T. Fujita, Y. Kanakura, S Komiya, and A. Yoshimura. 1997. A new protein containing an $\mathrm{SH} 2$ domain that inhibits JAK kinases. Nature 387: 921-924.

Fujii, H., Y. N akagawa, U. Schindler, A. Kawahara, H. M ori, F. Gouilleux B. Groner, J.N. Ihle, Y. Minami, T. M iyazaki, and T. Taniguchi. 1995. Activation of Stat 5 by interleukin-2 requires a carboxyl-terminal region of the interleukin-2 receptor $\beta$ chain but is not essential for the proliferative signal transmission. Proc. Natl. Acad. Sci. 92: 5482-5486.

Gossen, M., S. Freundlieb, G. Bender, G. Muller, W. Hillen, and H. Bujard. 1995. Transcriptional activation by tetracyclines in mammalian cells. Science 268: 1766-1769.

Hatakeyama, M., H. M ori, T. Doi, and T. Taniguchi. 1989. A restricted cytoplasmic region of IL-2 receptor $\beta$ chain is essential for growth signal transduction but not for ligand binding and internalization. Cell 59: 837-845.

Ihle, J.N . 1995. Cytokine receptor signaling. Nature 377: 591-594.

- - 1996. STATs: Signal transducers and activators of transcription. Cell 84: 331-334.

Ishii, N., H. Asao, Y. Kimura, T. Takeshita, M. Nakamura, S. Tsuchiya, T. Konno, M. Maeda, T. U chiyama, and K. Sugamura. 1994. Impairment of ligand binding and growth signaling of mutant IL-2 receptor $\gamma$-chains in patients with $\mathrm{X}$-linked severe combined immunodeficiency. J. Immunol. 153: 1310-1317.

Johnston, J.A., M. Kawamura, R.A. Kirken, Y.Q. Chen, T.B. Blake, K. Shibuya, J.R. Ortaldo, D.W. McVicar, and J.J. O'Shea. 1994. Phosphorylation and activation of the Jak-3 Janus kinase in response to interleukin-2. Nature 370: 151-153.

Kawahara, A., Y. M inami, and T. Taniguchi. 1994. Evidence for a critical role for the cytoplasmic region of the interleukin-2 receptor $\gamma$ chain in IL-2, IL-4, and IL-7 signaling. Mol. Cell. Biol. 14: 5433-5440.

Kawahara, A., Y. M inami, T. Miyazaki, J.N . Ihle, and T. Taniguchi. 1995. Critical role of the interleukin-2 (IL-2) receptor $\gamma$-chain-associated Jak3 in the IL-2-induced c-fos and c-myc, but not bcl-2 gene induction. Proc. Natl. Acad. Sci. 92: 8724-8728.

Leonard, W.J., M. N oguchi, S.M. Russell, and O.W. McBride. 1994.The molecular basis of $X$-linked severe combined immunodeficiency: The role of the interleukin- 2 receptor $\gamma$ chain as a common $\gamma$ chain, $\gamma \mathrm{C}$. Immunol. Rev. 138: 61-86.

Lev, S., H. Moreno, R. Martinez, P. Canoll, E. Peles, J.M. Musacchio, G.D. Plowman, B. Rudy, and J. Schlessinger. 1995. Protein tyrosine kinase PYK2 involved in $\mathrm{Ca}^{2+}$-induced regulation of ion channel and
MAP kinase functions. Nature 376: 737-745

Minami, Y., I. Oishi, Z.J. Liu, S. N akagawa, T. Miyazaki, and T. Taniguchi. 1994. Signal transduction mediated by the reconstituted IL-2 receptor: Evidence for a cell type-specific function of IL-2 receptor $\beta$-chain. J. Immunol. 152: 5680-5690.

Minami, Y., Y. N akagawa, A. Kawahara, T. Miyazaki, K. Sada, H. Yamamura, and T. Taniguchi. 1995. Protein tyrosine kinase Syk is associated with and activated by the IL- 2 receptor: Possible link with the c-myc induction pathway. Immunity 2: 89-100.

Miyazaki, T. and T. Taniguchi. 1996. Coupling of the IL2 receptor complex with non-receptor protein tyrosine kinases. Cancer Surv. 27: 2540.

Miyazaki, T., M. M aruyama, G. Yamada, M. Hatakeyama, and T. Taniguchi. 1991. The integrity of the conserved "WS motif" common to IL-2 and other cytokine receptors is essential for ligand binding and signal transduction. EMBO J. 10: 3191-3197.

Miyazaki, T., A. Kawahara, H. Fujii, Y. N akagawa, Y. Minami, Z.J. Liu, I. Oishi, O. Silvennoinen, B.A. Witthuhn, J.N. Ihle, and T. Taniguchi. 1994. Functional activation of Jak 1 and Jak 3 by selective association with IL-2 receptor subunits. Science 266: 1045-1047.

N aka, T., M. N arazaki, M. Hirata, T. M atsumoto, S. M inamoto, A. Aono, N. Nishimoto, T. Kajita, T. Taga, K. Yoshizaki, S. Akira, and T. Kishimoto. 1997. Structure and function of a new STAT-induced STAT inhibitor. Nature 387: 924-929.

N elson, B.H., J.D. Lord, and P.D. Greenberg. 1996. A membrane-proximal region of the interleukin-2 receptor $\gamma c$ chain sufficient for Jak kinase activation and induction of proliferation in T cells. Mol. Cell. Biol. 16: 309-317.

Qian, D., S. Lev, N.S.C. van Oers, I. Dikic, J. Schlessinger, and A. Weiss. 1997. Tyrosine phosphorylation of Pyk2 is selectively regulated by Fyn during TCR signaling. J. Exp. Med. 185: 1253-1259.

Russell, S.M., J.A. Johnston, M. N oguchi, M. Kawamura, C.M. Bacon, M Friedmann, M. Berg, D.W. McVicar, B.A. Witthuhn, O. Silvennoinen, A.S. Goldman, F.C. Schmalstieg, J.N. Ihle, J.J. O'Shea, and W.J. Leonard. 1994. Interaction of IL-2R $\beta$ and $\gamma \mathrm{C}$ chains with JakI and Jak3. Implications for XSCID and XCID. Science 266: 1042-1045.

Sasaki, H., K. N agura, M. Ishino, H. Tobioka, K. Kotani, and T. Sasaki. 1995. Cloning and characterization of cell adhesion kinase $\beta$, a novel protein-tyrosine kinase of the focal adhesion kinase subfamily. J. Biol. Chem. 270: 21206-21219.

Stahl, N., T.J. Farruggella, T.G. Boulton, Z. Zhong, J.E. Darnell Jr., and G.D. Yancopoulos. 1995. Choice of STATs and other substrates specified by modular tyrosine-based motifs in cytokine receptors. Science 267: 1349-1353.

Starr, R., T.A. Willson, E.M. Viney, L.J. Murray, J.R. Rayner, B.J. Jenkins, T.J. Gonda, W.S. Alexander, D. M etcalf, N.A. N icola, and D.J. Hilton. 1997. A family of cytokine-inducible inhibitors of signaling. Nature 387: 917-921.

Sugamura, K., H. Asao, M. Kondo, N. Tanaka, N. Ishii, K. Ohbo, M. $\mathrm{N}$ akamura, and T. Takeshita. 1996. The interleukin-2 receptor $\gamma$ chain: Its role in the multiple cytokine receptor complexes and T cell development in XSCID. Annu. Rev. Immunol. 14: 179-205.

Takeshita, T., Y. Goto, K. Tada, K. N agata, H. Asao, and K. Sugamura 1989. Monoclonal antibody defining a molecule possibly identical to the p75 subunit of interleukin 2 receptor. J. Exp. Med. 169: 13231332.

Takeshita, T., T. Arita, M. Higuchi, H. Asao, K. Endo, H. Kuroda, N Tanaka, K. M urata, N. Ishii, and K. Sugamura. 1997. STAM, signal transducing adaptor molecule, is associated with Janus kinases and involved in signaling for cell growth and c-myc induction. Immunity 6: 449-457.

Taniguchi, T. 1995. Cytokine signaling through nonreceptor protein tyrosine kinases. Science 268: 251-255

Taniguchi, T. and Y. Minami. 1993. The IL-2/IL-2 receptor system: A current overview. Cell 73: 5-8.

Tokiwa, G., I. Dikic, S. Lev, and J. Schlessinger. 1996. Activation of Pyk2 by stress signals and coupling with JNK signaling pathway. Science 273: 792-794.

Witthuhn, B.A., O. Silvennoinen, O. Miura, K.S. Lai, C. Cwik, E.T. Liu, and J.N. Ihle. 1994. Involvement of the Jak-3 Janus kinase in signaling by interleukins 2 and 4 in lymphoid and myeloid cells. Nature 370: 153-157. 


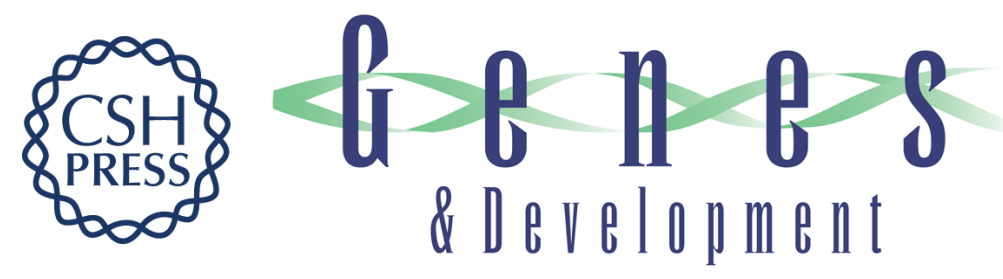

\section{Pyk2 is a downstream mediator of the IL-2 receptor-coupled Jak signaling pathway}

Tadaaki Miyazaki, Akinori Takaoka, Leonor Nogueira, et al.

Genes Dev. 1998, 12:

References This article cites 36 articles, 19 of which can be accessed free at:

http://genesdev.cshlp.org/content/12/6/770.full.html\#ref-list-1

License

Email Alerting

Receive free email alerts when new articles cite this article - sign up in the box at the top

Service right corner of the article or click here.

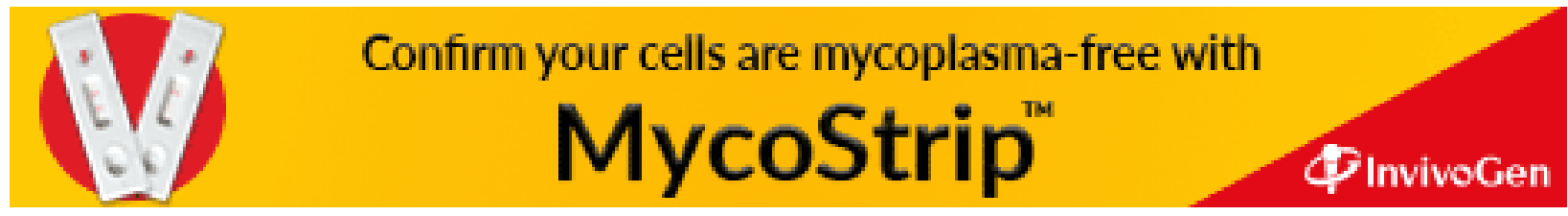

